\title{
Studi Pengembangan Pasar Tradisional Pajak Ikan Sebagai Pusat Wisata Belanja Di Kota Medan
}

Femmy Indriany Dalimunthe a,1

1femmydalimunthe@gmail.com

a Politeknik Pariwisata Medan, Jl. Rumah Sakit Haji No. 12 Medan, Medan 20371 Indonesia

\begin{abstract}
This study aims to describe a picture of how potential is and what the appropriate development strategy for a traditional market in Medan, Pajak Ikan. This research was conducted by using descriptive method. The data was collected by interview and observation. Interviews were conducted with a few selected outlets randomly(random sampling). And observations conducted with the involvement of information from many parties involved, include society community and local government. Implementation of these research activities carried out for 10 months, starting from the preparation of proposals that have been field since December 2018 to September 2019.

The results showed that Pajak Ikan in Medan has the potential to be developed into a shopping center in the city of Medan. Then for alternative development strategies that best fit based on the results of the analysis is a strategy QSPM SO1 (Strength-Opportunity) is a strategy that uses the internal strangth to take advantage of external opportunities that exist in the way of executing many events with grand publications in the area of Pajak Ikan.
\end{abstract}

\section{Keywords : potential shopping center, matrix TOWS, strategy}

\section{PENDAHULUAN}

Pembangunan pariwisata di Indonesia menunjukkan kecenderungan meningkat dari beberapa dekade sebelumnya. Konsumsi jasa dalam bentuk komoditas wisata bagi sebagaian masyarakat Indonesia telah menjadi salah satu kebutuhan akibat meningkatnya pendapatan, aspirasi dan kesejahteraannya.

Wisata belanja merupakan trend perkembangan wisata saat ini. Sejak dahulu konsep shopping tour telah dimulai dengan peranana souvenir center sebagai salah satu tempat yang patut dikunjungi wisatawan. Dinamika pariwisata yang cepat membawa perubahan konsep pariwisata dan pariwisata massal 'pariwisata baru' yang berkesan lebih ramah lingkungan dan berdaya guna untuk memberdayakan masyarakat lokal, maka hal tersebut memberikan dampak positif munculnya trend wisata belanja yang juga lebih baru dan fresh.

Kota Medan sebagai kota terbesar ketiga di Indonesia merupakan salah satu pintu gerbang utama masuknya wisatawan mancanegara dan juga destinasi utama kunjungan wisatawan domestik. Dalam konteks wisata belanja, kota Medan merupakan salah satu pilihan utama. Terdapat banyak lokasi belanja dengan aneka macam produk ada di kota Medan dengan kategori tradisional hingga modern.
Salah satu lokasi wisata terkenal di kota Medan adalah Pajak Ikan. Pajak dalam bahasa setempat seperti pasar. Pajak Ikan merupakan salah satu lokasi wisata belanja yang potensial. Walaupun namanya Pajak Ikan, namun komoditi yang dijual adalah komoditi tekstil. Selain nama yang unik, Pajak Ikan memiliki beberapa keunggulan lainnya sehingga layak untuk dikembangkan sebagai kawasan wisata belanja di kota Medan. Lokasinya yang strategis, varian produk yang banyak dan harga yang ditawarkan relatif murah merupakan modal utama. Saat ini, nama pajak ikan sudah dikenal meluas, maka tak jarang dijumpai pelancong dari luar seperti Malaysia, Tahiland dan Singapura yang berbelanja di Pajak Ikan.

Tetapi potensi pajak ikan masih belum bisa dimaksimalkan untuk menambah pemasukan dalam kaitannya sebagai lokasi dan daya tarik wisata belanja. Terbukti banyak travel agent belum mempertimbangkan pajak ikan sebagai salah satu daya tarik wisata yang wajib dikunjungi jika datang ke kota Medan. Pajak ikan memerlukan langkah-langkah kebijakan kongkrit dan operasional guna tercapainya kemantapan pengelolaan objek wisata belanja di era globalisasi dan otonomi daerah. Sesuai dengan keunikan kekayaan spesifik lokasi yang dimiliki, setiap daerah dan setiap objek wisata dapat menentukan sasaraan dan bidang garapan pasar yang dapat dituju. 
Oleh sebab itu, diperlukan penelitian komprehensif untuk mengidentifikasi terlebih dahulu ancaman, peluang, kelemahan dan kekuatan Pajak Ikan sebagai daya tarik wisata belanja di pasar tradisional Pajak Ikan yang temuan penelitiannya disampaikan pada artikel ilmiah ini.

\section{TINJAUAN PUSTAKA}

Sebagai pedoman dan dasar pemecahan masalah dalam penelitian ini diperlukan landasan teoritis. Ada 3 ruang lingkup teori yang akan digunakan, yaitu mengenai studi pengembangan yang berpusat pada nilai perencanaan berbasis metode TOWS, konsep pasar tradidional dan konsep wisata belanja.

Terdapat beberapa jenis pengembangan, yaitu:

a. Keseluruhan dengan tujuan baru, membangun atraksi di situs yang tadinya tidak digunakan sebagai atraksi.

b. Tujuan baru, membangun atraksi pada situs yang sebelumnya telah digunakan sebagai atraksi.

c. Pengembangan baru secara keseluruhan pada keberadaan atraksi yang dibangun untuk menarik pengunjung lebih banyak dan untuk membuat atraksi tersebut dapat mencapai pasar yang lebih luas, dengan meraih pangsa pasar yang baru.

d. Pengembangan baru pada keberadaan atraksi yang bertujuan untuk meningkatkan fasilitas pengunjung atau mengantisipasi meningkatnya pengeluaran sekunder oleh pengunjung.

e. Penciptaan kegiatan-kegiatan baru atau tahapan dari kegiatan yang berpindah dari satu tempat ke tempat lain dimana kegiatan tersebut memerlukan modifikasi bangunan dan struktur.

\section{METODE PENELITIAN}

\subsection{Metode dan Unit Analisis Penelitian}

Skema Matriks Tows

3.1. Metode dan Unit Analisis Penelitian
\begin{tabular}{|c|c|c|}
\hline \multirow{3}{*}{ Skema Matriks TOWS } & KELEMAHAN \\
& KEKUATAN & Daftar Kelemahan \\
& Daftar Kekuatan & $5-10$ \\
\hline PELUANG - 0 & $5-10$ & STRATEGI - WO \\
\hline
\end{tabular}

menggunakan metode deskriptif. Tjahjo (1999:6) mengungkapkan bahwa metode penelitian deskriptif bertujuan membuat gambaran secara sistematis, faktual dan akurat mengenai fakta-fakta dan sifat-sifat dari populasi atau daerah tertentu yang dijadikan objek atau subjek penelitian, sehingga gambaran tersebut merupakan suatu pemikiran tentang pariwisata yang sedang berlangsung pada saat penelitian dilakukan. Nazir (1998:263) menjelaskan bahwa metode deskriptif adalah suatu metode yang menelitian suatu set kondisi yang meliputi survey, deskriptif berkesinambungan, studi kasus, analisis pekerjaan dan aktivitas, kaji tindak, penelitian kepustakaan dan dokumenter. Penelitian deskriptif mempelajari tata cara yang berlaku dalam masyarakat, situasi-situasi tertentu, hubungan kegiatan-kegiatan, sikapsikap, pandangang-pandangan dan prosesproses yang sedang berlangsung.

Kemudian Masri Singarimbun (1995:84) menjelaskan bahwa penelitian deskriptif memiliki dua tujuan. Pertama adalah untuk mengetahui perkembangan sarana fisik tertentu. Kedua adalah untuk mendeskripsikan secara terperinci fenomena-fenomena sosial tertentu yang dijumpai secara mendalam, juga menerangkan hubungan pengujian hipotesis, membuat prediksi, interprestasi dari suatu masalah yang ingin dipecahkan sehingga menghasilkan pemikiran-pemikiran sebaga upaya pemecahan masalah yang dihadapi.

Dalam metode ini analisis dilakukan pada identifikasi masdalah dan penjabaran terhadap data yang dikumpulkan dengan berpedoman pada konsep-konsep studi kepustakaan yang relevan. Sehingga dihasilkan deskripsi atau gambaran secara sistematis, faktual, dan akurat mengenai potensi yang dimiliki oleh pasara tradisional Pajak Ikan sebagai pusat wisata belanja di kota Medan. 


\begin{tabular}{|c|c|c|}
\hline Daftar Peluang & $\begin{array}{c}\text { Gunakan kekuatan untuk } \\
\text { memanfaatkan peluang }\end{array}$ & $\begin{array}{c}\text { Atasi kelemahan dengan } \\
\text { memanfaatkan peluang }\end{array}$ \\
\hline ANCAMAN - T & STRATEGI ST & STRATEGI WT \\
Daftar Ancaman & $\begin{array}{c}\text { Gunakan kekuatan untuk } \\
\text { menghindari ancaman }\end{array}$ & $\begin{array}{c}\text { Minimalkan kelemahan } \\
\text { dan menghindari } \\
\text { ancaman }\end{array}$ \\
\hline $5-10$ & & ancan \\
\hline
\end{tabular}

Dalam menentukan strategi-strategi alternatif digunakan QSPM (Quantitative Strategic Planning Matrix), untuk menentukan daya tarik relatif dari strategi-strategi yang di dasarkan sampai seberapa jauh faktor-faktor keberhasilan kritis eksternal dan internal kunci dimanfaatkan atau ditingkatkan.

\section{HASIL DAN PEMBAHASAN}

\subsection{Faktor Strategi Internal}

\section{Kekuatan (Strength)}

a. Pada beberapa bagian, di Pajak Ikan terdapat bau-bau khas dupa atau parfumparfum Arab yang menarik. Jika dikembangkan hal ini bisa menjadi salah satu titik kemenarikan Pajak Ikan.

b. Interaksi dagang juga menjadi salah satu kekuatan pajak ikan. Sistem dagang yang ada adalah sistem tawar menawar (bargaining system), dimana harga yang disebutkan pedagang dapat ditawar oleh pembeli sehingga mengahsilkan harga yang disepakati. Hal ini sangat lumrah ditemui juga dipasar tradisional lainnya. Namun terdapat unsur menarik lainnya dari interaksi dagang yang ada, yaitu pedagang mau menerima mata uang asing (umumnya ringgit dan dolar singapura) dalam transaksinya.

c. Kebersihan udaara disekitar areal pajak ikan masih masuk kategori baik. Walaupun pada ruas utama jalan perniagaan pengunjung akan merasa sedikit sesak karena asap kendaraan.

d. Peran serta dan dukungan masyarakat sekitar sangat luar biasa terhadap perkembangan pajak ikan. Indikatornya adalah partisipasi untuk memberikan kritik dan saran terhadap perbaikan pajak ikan. Misalnya masyarakat sekitar peka dan peduli terhadap kondisi parkir yang ada sehingga muncullah sebuah tesis yang membahas rencana parkir yang lebij baik lagi bagi pajak ikan.

e. Salah satu kekuatan pajak ikan adalah keberadaannya yang strategis dan dekat dengan banyak lokasi penedia jasa akomodasi. Dapat dijumpai hotel-hotel besar seperti Grand Aston Hotel, Inna Dharma Deli, Arya Duta, Swissbel International Hotel, dan beberapa wisma yang menyediakan kamar-kamar murah meriah.

f. Fasilitas restaurant juga dapat dijumpai pada wilayah pajak ikan dan sekitarnya. Restoran yang adapun beragam, mulai dari yang menawarkan makanan lokal, chinese food hingga western food. Bahkan disekitar pajak ikan terdapat restaurant yang dianggap paling prestisius di Medan, yaitu Tip Top Medan yang menyajikan banyak makanan menarik dan lezat. Selain itu tidak jauh dari pajak ikan terdapat Merdeka Walk, sebuah pusat lokasi kuliner remaja dengan ciri makanan cepat saji, junk food dan continental food.

g. Pajak ikan merupakan salah satu souvenir center di Kota Medan. Banyak kain ulos dan beragam souvenir berjenis tekstil dijual di pajak ikan.

h. Kekuatan utama pajak ikan terletak di lokasinya yang strategis, bukan hanya karena akomodasi dan restoran yang dekat, melainkan juga karena dekatnya objek wisata lainnya sebagai pendukung kunjungan ke pajak ikan. Disadari atau tidak, dalam memilih kunjungan ke suatu kota,lebih banyak disadari pada pilihan objek yang akan dikunjungi. Suatu hal yang mustahil jika pengunjung datang ke Medan hanya karena ingin mengunjungi pajak ikan saja. Oleh sebab itu, keberadaan objek wisata lain akan menjadi faktor pendukung tingkat 
kunjunga ke pajak ikan. Dan beruntungnya, beberapa objek wisata yang menjadi pilihan pengunjung berada dilokasi yang berdekatan dengan pajak ikan. Objek wisata sekitar pajak ikan anatra lain : Rumah Tjong A Fie, Kesawan Square, Merdeka Walk, Post Office Old Building, Vihara Setia Budi dan Stasiun Kereta Api Pusat.

i. Sumber air yang ada di pajak ikan dapat diakses dengan baik.

j. Sistem pembuangan di pajak ikan juga tergolong baik. Hal ini ditekankan pada sistem pembuangan sampah kotoran WC yang dilayani Dinas Kebersihan kota Medan. Setiap bak sampah pemda diberihkan setiap pagi untuk diangkut ke pmbuangan akhir.

2. Kelemahan (Weakness)

a. Ruang gerak pengunjung kurang leluasa. Jalanan di gang antara satu outlt yang berhadapan terasa sesak, apalagi jika di musim yang lebih ramai, selain itu besaran toko juga kurang memberikan kesempatan untuk pengunjung bergerak dengan leluasa.

b. Pajak ikan di kota Medan menjadi salah satu bentuk semrawutnya penataan pasar seperti lazimnya pasar tradisional di kota lainnya. Tidak teraturnya parkir kendaraan dan kedai-kedai non ruko menjadi penyebab utama masalah ini.

c. Buku-buku atau leaflet promosi penjualan belum ada di pajak ikan. Media ini dapat menjadi petunjunk bagi pembeli mengenai barang-barang dan produk yang ditawarkan oleh pedangang.

d. Selain berbelanja dan makan, tidak ada piihan kegiatan yang bisa dilakukan oleh pengunjung ketika mendatangi pajak ikan. Belum ada atraksi gunting kain atau atraksi seni yang bisa ditampilkan di sepanjang ruas jalan kepada pengunjung.

e. Faktor keselamatan pengunjung dan pedagang juga belum bisa diidentifikasi. Keselamatan merupakan salah satu hal yang wajib dipertimbangkan ketika membuka lokasi umum. Dengan komoditi garmen dan tekstil, bahaya terbesar yang mengancam pajak ikan adalah kebakaran.

f. Keberadaan petugas kemanan belum terlihat di pajak ikan. Pada beberapa waktu tertentu, tampak dipersipakan beberapa polisi atau pamong praja untuk mengamankan lokasi pajak ikan, seperti pada musim ramai menjelang lebaran. Namun pada hari normal, tidak ada petugas khusus di bagian kemanan yang memantau kondisi kemanan di pajak ikan.

g. Dari 300an outlet yang ditata, hanya beberapa outlet yang memiliki tenaga khusus pramuwisata lokal.

h. Belum adanya organisasi pengelola pajak ikan yang dapat menjambatani kepentingan pedagang dan stakeholder dalam perkembangan pajak ikan menuju ke arah yang lebih baik.

i. Pelayanan kepada pelanggan masih sangat kurang.penerapan prinsip pelayanan prima dan tamu adalah raja masih sangat jauh di pajak ikan. Gerakan menarik-narik pengunjung untuk mampir ke toko, senyuman yang kurang dan kurang bersahabat dalam transaksi menjadi indikator kesimpulan ini.

j. Fasilitas tourist infomration center belum tersedia di pajak ikan. Tempat seperti ini merupakan salah satu unsur wajib jika ingin membangung sebuah tempat wisata. Tourist information center dapat memberikan petunjuk dan layanan awal kepada pengunjung yang datang sebelum mereka berinteraksi dengan pedagang. Tourist information center biasanya dikelola oleh pemerintah daerah dan menajdi titik pusat peneglolaan fasilitas umum lokasi serta kemanan.

k. Security center sebagai pusat informasi keamanan juga belum tersedia.

1. Fasilitas klinik juga belum tersedia di pajak ikan.

m. Pajak ikan dapat diakses dari banyak arah, seharusnya hal ini menjadi kekuatan bagi pajak ikan, sayangnya dengan aksesibilitas yang seperti ini, tidak terdapat pintu utama yang ditandai oleh entrance gate bagi pajak ikan.

\subsection{Faktor Strategi Eksternal}

1. Peluang (Opportunity)

a. Pemerintah daerah memiliki kepekaan terhadap keberadaan pajak ikan dengan memfasilitasi aksesibilitas dari dan menuju lokasi ini.

b. Masih dari sudut aksesibilitas, pajak ikan berada persis berdampingan dengan stasiun kereta api di Sumatera Utara. Hal 
ini membuka peluang lebih besar untuk kunjungan ke pajak ikan dari segmen pasar lokal, yaitu daerah-daerah Binjai, Padang Sidempuan, Siantar dan lain-lain.

c. Jaringan komunikasi di pajak ikan disini dimaksudkan pada jangkauan sinyal untuk berkomunkikasi dan akses dunia luar terhadap pajak ikan dalama komunikasi maya. Untuk jangkauan sinyal dipajak ikan sangat baik, karena berada di pusat kota.

\subsection{Ancaman (Threat)}

a. Tidak ada lahan kosong yang masih bisa dikembangkan di pajak ikan. Dengan lokasinya yang berada di pusat kota, setiap jengkal tanah di pajak ikan telah berubah menjadi bangunan dan jalanan. Untuk pengembangan pembangunan hanya akan berkutat pada pemanfaatan gedung yang telah ada atau perombakan besar yang pasti memakan waktu panjang dan biaya yang besar.

b. Sumber pembangkit listrik di pajak ikan bergantung pada perusahaan listrik negara (PLN) sebagai satu-satunya perusahaan nasional penyedia energi listrik. Saat ini,kondisi PLN di Medan lebih banyak dihujat dari pada diuji. Tingginya frekuensi pemadaman bergilir menyebabkan kondisi yang kurang nyaman bagi masyarakat secara umum.

c. Dengan tidak adanya security center dan ptugas keamanan, maka jaminan keamanan di pajak ikan menjadi mengkhawatirkan. Kemanan disini bukan hanya berkisar pada maslah aman dari pencuri dan pengutilan. Namun juga rasa aman karena sistem keselamatan yang jelas.

d. Pada bagian kekuatan, disebutkan bahwa jaringan komunikasi dapat menjadi kekuatan bagi perkembangan pajak ikan. Naumn hingga ssat ini sistem informasi perjalanan di pajak ikan masih belum terkoordinasi dengan baik. Ibaratkan telah memiliki jalan namun tidak ada mobil yang dapat ditumpangi, maka pajak ikan terancam akan mengalami kesulitasn untuk dikenal.

e. Kepastian tarif angkutan menuju pajak ikan ini juga dapat menjadi ancaman. Tarif angkutan pesawat saat ini berada pada level persaingan bebas, dimana kondisi pasar lah yang menentukan batasan harga. Untuk angkutan kereta api, hingga saat ini kondisi tarif masih dapat terjangkau.

\subsection{Tahap Analisis Faktor/Masukan (Matriks TOWS)}

Tabel Matriks untuk Pasar Tradisional Pajak Ikan

\begin{tabular}{|c|c|c|}
\hline Internal & Kekuatan S & Kelemahan W \\
\hline $\begin{array}{l}\text { Eksternal } \\
\text { Factor } \\
\text { Analisys }\end{array}$ & $\begin{array}{l}\text { 1. Adanya bagian-bagian pasar } \\
\text { yang terlihat menarik dengan } \\
\text { wewangian yang khas } \\
\text { 2. Interaksi dagang yang terlihat } \\
\text { sangat memudahkan } \\
\text { kepentingan pengunjung } \\
\text { 3. Kebersihan udara tergolong } \\
\text { baik dan } \\
\text { 4. Masyarakat mendukung dan } \\
\text { selalu berperan dalam } \\
\text { perkembangan pajak ikan } \\
\text { 5. Dekat dengan lokasi akomodasi } \\
\text { yang beragam } \\
\text { 6. Dekat dengan fasilitas } \\
\text { restoran/rumah makan } \\
\text { 7. Merupakan salah satu dari } \\
\text { sedikit tempat yang menjual } \\
\text { souvenir di kota Medan } \\
\text { 8. Dekat dengan objek wisata lain } \\
\text { sebagai pendukung } \\
\text { 9. Kemudahan dalam meperoleh }\end{array}$ & $\begin{array}{l}\text { 1. Terbatasnya ruang gerak pengunjung } \\
\text { 2. Pemandangan tidak terlalu baik } \\
\text { karena parkir dan penataan tokko } \\
\text { non ruko yang berantakan } \\
\text { 3. Belum adanya media cetak promosi } \\
\text { 4. Tidak adanya pilihan kegiatan di } \\
\text { pajak ikan } \\
\text { 5. Prosedur keselamatan pengunjung } \\
\text { tidak ada } \\
\text { 6. Petugas keamanan belum tersedia } \\
\text { 7. Pramuwisata lokal sangat minim } \\
\text { 8. Tidak adanya organisasi pengelola } \\
\text { 9. Sikap, pengetahuan dan keterampilan } \\
\text { dalam melayani pengunjung masih } \\
\text { sangat kurang } \\
\text { 10. Belum adanya tourist information } \\
\text { center } \\
\text { 11. Belum adanya security center } \\
\text { 12. Belum adanya } \\
\text { kesehatan klinik/pusat } \\
\text { 13. Tidak adanya entrance gate utama }\end{array}$ \\
\hline
\end{tabular}




\begin{tabular}{|c|c|c|}
\hline & $\begin{array}{l}\text { sumber air } \\
\text { 10. Sistem pembuangan dan sistem } \\
\text { kebersihan hilir sudah baik }\end{array}$ & $\begin{array}{l}\text { 14. Parking area tidak tertata rapi } \\
\text { 15. Fasilitas tempat sampah kurang } \\
\text { memadai } \\
\text { 16. Tidak adanya fasilitas toilet umum } \\
\text { 17. Fasilitas ibadah juga belum tersedia }\end{array}$ \\
\hline Peluang - 0 & Strategi SO & $\begin{array}{c}\text { Stratgei WO } \\
\end{array}$ \\
\hline $\begin{array}{l}\text { 1. Pemda memeiliki tekad } \\
\text { untuk berperan dalam } \\
\text { perkembangn pajak ikan } \\
\text { 2. Akses jalan fisik baik dan } \\
\text { terus diperbaiki } \\
\text { 3. Dekat dengan stasiun } \\
\text { kereta api } \\
\text { 4. Jaringan komunikasi } \\
\text { tersedia }\end{array}$ & $\begin{array}{l}\text { 1. Mengadakan event-event atau } \\
\text { kontes }(01, \mathrm{~S} 1, \mathrm{~S} 2)\end{array}$ & $\begin{array}{l}\text { 1. Penyediaan fasilitas } \begin{array}{r}\text { untuk } \\
\text { mendukung pelaksanaan } \\
\text { wisata } \\
\text { kegiatan }\end{array} \\
\text { 16,W17) } \\
\text { 2. Perbaikan fasilitas kebersihan hulu } \\
\text { (01,W15) } \\
\text { 3. Pembentukan organisasi guna } \\
\text { melatih dan memberdayakan SDM } \\
\text { (01,W5,W6,W7,W8) } \\
\text { 4. Maksimalisasi TIS Bandara untuk } \\
\text { mendukung perkembangan wisata } \\
\text { pajak ikan (03,W3,W10) }\end{array}$ \\
\hline Ancaman - T & Strategi ST & Strategi WT \\
\hline $\begin{array}{l}\text { 1. Terbatasnya lahan untuk } \\
\text { pembangunan } \\
\text { 2. Listrik yang kerap } \\
\text { bermasalah } \\
\text { 3. Sistem keamanan yang } \\
\text { belum ada } \\
\text { 4. Tidak adanya sistem } \\
\text { informasi perjalanan } \\
\text { 5. Tidak adanya kepastian } \\
\text { tarif }\end{array}$ & $\begin{array}{l}\text { 1. } \\
\text { Zonasi }\end{array}$ & $\begin{array}{l}\text { 1. Penataan ruang dan toko yang lebih } \\
\text { berorientasi pada fungsi (T1,W1,W2) } \\
\text { 2. Pengembangan sistem keselamatan } \\
\text { dan kemanan dalam lingkup sistem } \\
\text { informasi perjalanan terpadu (T2,W5) }\end{array}$ \\
\hline
\end{tabular}

Tujuan dari setiap perangkat pencocokan matriks TOWS adalah untuk mengahsilkan strategi alternatif yang dapat dijalankan, tetapi bukan untuk memilih atau menetapkan strategi mana yang terbaik. Oleh karena itu tidak semua strategi yang dikembangkan dalam matriks TOWS akan dipilih untuk dijalankan.

Terdapat empat strategi yang dihasilkan dalam matriks TOWS untuk pengembangan outlet tanaman hias, yaitu :

1. Strategi SO atau strategi kekuatan - peluang dengan menggunakan kekuatan internal untuk memanfaatkan peluang eksternal. Strategi SO yang dihasilkan oleh matriks TOWS pada pasar tradisional pajak ikan adalah dengan menggunakan kekuatan internal untuk memanfaatkan peluang eksternal pada outlet tanaman hias, menghasilkan solusi dengan strategi.

2. Strategi WO atau strategi kelemahan peluang dengan memperbaiki kelemahan internal untuk memanfaatkan peluang eksternal. Stratgei WO yang dihasilkan oleh matriks TOWS pada pajak ikan adalah dengan memperbaiki kelemahan internal untuk memanfaatkan peluang eksternal pada outlet tanaman hias, menghasilkan solusi dengan strategi.

3. Strategi ST atau strategi keuatan - ancaman dengan menggunakan kekuatan internal untuk menghindari atau mengurangi dampak ancaman eksternal. Strategi ST yang dihasilkan oleh matriks TOWS pada pajak ikan adalah dengan menggunakan kekuatan internal untuk menghindari atau mengurangi dampak ancaman eksternal pada outlet tanaman hias, menghasilkan solusi dengan strategi.

4. Strategi WT atau strategi kelemahan ancaman yaitu taktif defensif yang mengarahkan untuk mengurangi kelemahan internal dan untuk menghindari ancaman eksternal. Strategi WT yang dihasilkan oleh matriks TOWS pada pajak ikan adalah dengan mengurangi ancaman internal untuk menghindari ancaman eksternal pada outlet tanaman hias menghasilkan solusi yaitu dengan strategi.

\subsection{Tahap Keputusan QSPM}


Dalam tahap keputusan ini adalah merupakan langkah penentuan atau perumusan strategi dari strategi-strategi alternatif yang telah dihasilkan dalam tahap analisis faktor dengan menggunakan matrik TOWS. Strategistrategi alternatif yang dihasilkan tidak semuanya harus dijalankan atau dikembangkan.

Tabel Matriks Perencanaan Strategi Kuantitatif (Quantitative Strategic Planning Matrix)

\begin{tabular}{|c|c|c|c|c|c|c|c|c|c|c|c|c|c|c|c|c|c|}
\hline \multicolumn{18}{|c|}{ Alternative Strategy } \\
\hline & & \multicolumn{2}{|c|}{ S01 } & \multicolumn{2}{|c|}{ W01 } & \multicolumn{2}{|c|}{ W02 } & \multicolumn{2}{|c|}{ W03 } & \multicolumn{2}{|c|}{ W04 } & \multicolumn{2}{|c|}{ ST1 } & \multicolumn{2}{|c|}{ WT1 } & \multicolumn{2}{|c|}{ WT2 } \\
\hline \begin{tabular}{|l|} 
Kekuatan \\
(Strength) \\
\end{tabular} & Rating & AS & TAS & AS & TAS & AS & TAS & $\overline{A S}$ & TAS & AS & TAS & $\overline{A S}$ & TAS & AS & TAS & AS & TAS \\
\hline \begin{tabular}{|l|} 
1. Adanya \\
bagian- \\
bagian pasar \\
yang terlihat \\
menarik \\
dengan \\
wewangian \\
yang khas \\
\end{tabular} & 0.02 & 4 & 0.08 & 3 & 0.06 & 1 & 0.02 & 1 & 0.02 & 1 & 0.02 & 4 & 0.08 & 3 & 0.06 & 1 & 0.02 \\
\hline 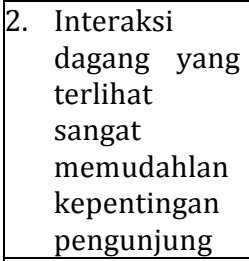 & 0.06 & 4 & 0.24 & 2 & 0.12 & 1 & 0.06 & 1 & 0.06 & 1 & 0.06 & 1 & 0.06 & 1 & 0.06 & 1 & 0.06 \\
\hline 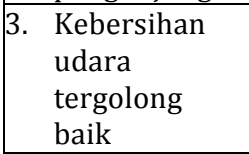 & 0.02 & 1 & 0.02 & 1 & 0.02 & 1 & 0.02 & 1 & 0.02 & 1 & 0.02 & 1 & 0.02 & 1 & 0.02 & 1 & 0.02 \\
\hline 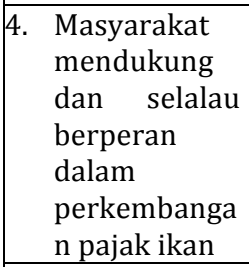 & 0.08 & 3 & 0.24 & 2 & 0.16 & 3 & 0.24 & 4 & 0.32 & 4 & 0.32 & 1 & 0.08 & 1 & 0.08 & 1 & 0.08 \\
\hline \begin{tabular}{|l} 
5. \\
Dekat dengan \\
lokasi \\
akmodasi \\
yang \\
beragam \\
\end{tabular} & 0.07 & 4 & 0.28 & 3 & 0.21 & 1 & 0.07 & 2 & 0.14 & 4 & 0.28 & 3 & 0.21 & 1 & 0.07 & 1 & 0.07 \\
\hline $\begin{array}{ll}6 . & \text { Dekat dengan } \\
& \text { fasilitas } \\
& \text { restoran/rum } \\
\text { ah makan }\end{array}$ & 0.06 & 4 & 0.24 & 4 & 0.24 & 2 & 0.12 & 2 & 0.12 & 4 & 0.24 & 3 & 0.18 & 1 & 0.06 & 2 & 0.12 \\
\hline 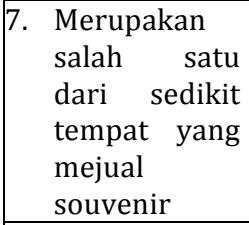 & 0.08 & 4 & 0.32 & 1 & 0.08 & 2 & 0.16 & 2 & 0.16 & 4 & 0.32 & 1 & 0.08 & 1 & 0.08 & 1 & 0.08 \\
\hline 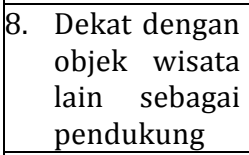 & 0.07 & 4 & 0.28 & 3 & 0.21 & 1 & 0.07 & 3 & 0.21 & 4 & 0.28 & 3 & 0.21 & 1 & 0.07 & 3 & 0.21 \\
\hline $\begin{array}{ll}\text { 9. } & \text { Kemudahan } \\
& \text { dalam } \\
\text { memperoleh } & \text { sumber air } \\
\end{array}$ & 0.02 & 1 & 0.02 & 1 & 0.02 & 1 & 0.02 & 1 & 0.02 & 1 & 0.02 & 1 & 0.02 & 1 & 0.02 & 1 & 0.02 \\
\hline \begin{tabular}{|l} 
10. Sistem \\
pembuangan
\end{tabular} & 0.02 & 1 & 0.02 & 1 & 0.02 & 1 & 0.02 & 1 & 0.02 & 1 & 0.02 & 1 & 0.02 & 1 & 0.02 & 2 & 0.04 \\
\hline
\end{tabular}




\begin{tabular}{|c|c|c|c|c|c|c|c|c|c|c|c|c|c|c|c|c|c|}
\hline \multicolumn{18}{|c|}{ Alternative Strategy } \\
\hline & & \multicolumn{2}{|c|}{ S01 } & \multicolumn{2}{|c|}{ W01 } & \multicolumn{2}{|c|}{ W02 } & \multicolumn{2}{|c|}{ W03 } & \multicolumn{2}{|c|}{ W04 } & \multicolumn{2}{|c|}{ ST1 } & \multicolumn{2}{|c|}{ WT1 } & \multicolumn{2}{|c|}{ WT2 } \\
\hline $\begin{array}{l}\text { dan sistem } \\
\text { kebersihan } \\
\text { hilir sudah } \\
\text { baik }\end{array}$ & & & & & & & & & & & & & & & & & \\
\hline \multicolumn{18}{|c|}{ Kelemahan (Weakness) } \\
\hline $\begin{array}{ll}\text { 1. } & \text { Terbatasnya } \\
\text { ruang gerak } \\
\text { pengunjung }\end{array}$ & 0.04 & 1 & 0.04 & 1 & 0.04 & 1 & 0.04 & 1 & 0.04 & 1 & 0.04 & 4 & 0.16 & 4 & 0.16 & 1 & 0.04 \\
\hline \begin{tabular}{|lr} 
2. & \multicolumn{2}{l}{ Pemandanga } \\
$\mathrm{n}$ & tidak \\
terlalu baik & karena parkir \\
dan pentaan \\
non ruko \\
yang \\
berantakan
\end{tabular} & 0.04 & 1 & 0.04 & 1 & 0.04 & 1 & 0.04 & 1 & 0.04 & 1 & 0.04 & 1 & 0.04 & 1 & 0.04 & 1 & 0.04 \\
\hline $\begin{array}{ll}\text { 3. } & \text { Belum } \\
\text { adnaya media } \\
\text { cetak } \\
\text { promosi }\end{array}$ & 0.06 & 4 & 0.24 & 1 & 0.06 & 1 & 0.06 & 1 & 0.06 & 4 & 0.24 & 1 & 0.06 & 1 & 0.06 & 4 & 0.24 \\
\hline $\begin{array}{l}\text { 4. } \text { Tidak adanya } \\
\text { pilihan } \\
\text { kegiatan lain } \\
\text { di pajak ikan }\end{array}$ & 0.06 & 4 & 0.24 & 1 & 0.06 & 1 & 0.06 & 1 & 0.06 & 1 & 0.06 & 1 & 0.06 & 1 & 0.06 & 1 & 0.06 \\
\hline 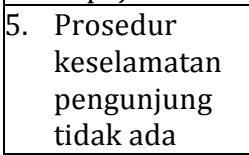 & 0.04 & 2 & 0.08 & 1 & 0.04 & 3 & 0.12 & 4 & 0.16 & 1 & 0.04 & 1 & 0.04 & 1 & 0.04 & 4 & 0.16 \\
\hline 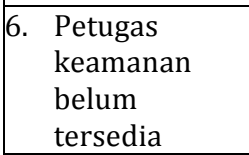 & 0.01 & 2 & 0.02 & 3 & 0.03 & 1 & 0.01 & 4 & 0.04 & 1 & 0.01 & 1 & 0.01 & 1 & 0.01 & 4 & 0.04 \\
\hline 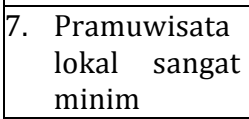 & 0.02 & 1 & 0.02 & 1 & 0.02 & 1 & 0.02 & 4 & 0.08 & 1 & 0.02 & 1 & 0.02 & 2 & 0.04 & 1 & 0.02 \\
\hline \begin{tabular}{|l} 
8. $\begin{array}{l}\text { Tidak adnya } \\
\text { organisasi } \\
\text { pengelola }\end{array}$ \\
\end{tabular} & 0.03 & 4 & 0.12 & 2 & 0.06 & 1 & 0.03 & 4 & 0.12 & 1 & 0.03 & 1 & 0.03 & 1 & 0.03 & 1 & 0.03 \\
\hline \begin{tabular}{|l|} 
9. \\
pikap, \\
pengetahuan \\
dan \\
keterampilan \\
dalam \\
melayani \\
pengunjung \\
masih sangat \\
kurang \\
\end{tabular} & 0.04 & 4 & 0.16 & 2 & 0.08 & 1 & 0.04 & 4 & 0.16 & 1 & 0.04 & 2 & 0.08 & 2 & 0.08 & 1 & 0.04 \\
\hline $\begin{array}{l}\text { 10. Belum } \\
\text { adanya } \\
\text { tourist } \\
\text { information } \\
\text { center }\end{array}$ & 0.04 & 2 & 0.08 & 2 & 0.08 & 1 & 0.04 & 4 & 0.16 & 4 & 0.16 & 1 & 0.04 & 2 & 0.08 & 4 & 0.16 \\
\hline \begin{tabular}{|l|}
11. Belum \\
adanya \\
security \\
center
\end{tabular} & 0.02 & 2 & 0.04 & 2 & 0.04 & 1 & 0.02 & 4 & 0.08 & 1 & 0.02 & 2 & 0.04 & 1 & 0.02 & 4 & 0.08 \\
\hline $\begin{array}{l}\text { 12. Belum } \\
\text { adanya klinik } \\
\text { kesehatan }\end{array}$ & 0.02 & 2 & 0.04 & 4 & 0.08 & 2 & 0.04 & 4 & 0.08 & 1 & 0.02 & 1 & 0.02 & 2 & 0.04 & 1 & 0.02 \\
\hline $\begin{array}{l}\text { 13. Tidak adanya } \\
\text { entrence gate } \\
\text { utana }\end{array}$ & 0.01 & 2 & 0.02 & 4 & 0.04 & 1 & 0.01 & 1 & 0.01 & 1 & 0.01 & 1 & 0.01 & 1 & 0.01 & 2 & 0.02 \\
\hline 14. Parking area & 0.02 & 2 & 0.04 & 4 & 0.08 & 1 & 0.02 & 1 & 0.02 & 1 & 0.02 & 1 & 0.02 & 1 & 0.02 & 1 & 0.02 \\
\hline
\end{tabular}


Vol. 7 No 2, 2019

\begin{tabular}{|c|c|c|c|c|c|c|c|c|c|c|c|c|c|c|c|c|c|}
\hline \multicolumn{18}{|c|}{ Alternative Strategy } \\
\hline & & \multicolumn{2}{|c|}{ S01 } & \multicolumn{2}{|c|}{ W01 } & \multicolumn{2}{|c|}{ W02 } & \multicolumn{2}{|c|}{ W03 } & \multicolumn{2}{|c|}{ W04 } & \multicolumn{2}{|c|}{ ST1 } & \multicolumn{2}{|c|}{ WT1 } & \multicolumn{2}{|c|}{ WT2 } \\
\hline \begin{tabular}{|ll} 
tidak tertata \\
rapi
\end{tabular} & & & & & & & & & & & & & & & & & \\
\hline $\begin{array}{l}\text { 15. Fasilitas } \\
\text { tempat } \\
\text { sampah } \\
\text { kurang } \\
\text { memadai }\end{array}$ & 0.02 & 3 & 0.06 & 4 & 0.08 & 1 & 0.02 & 1 & 0.02 & 1 & 0.02 & 1 & 0.02 & 1 & 0.02 & 2 & 0.04 \\
\hline $\begin{array}{l}\text { 16. Tidak adanya } \\
\text { fasilitas toilet } \\
\text { umum }\end{array}$ & 0.02 & 3 & 0.06 & 4 & 0.08 & 1 & 0.02 & 1 & 0.02 & 1 & 0.02 & 1 & 0.02 & 1 & 0.02 & 1 & 0.02 \\
\hline \begin{tabular}{|l} 
17. Fasilitas \\
ibadah juga \\
belum \\
tersedia \\
\end{tabular} & 0.01 & 2 & 0.02 & 4 & 0.04 & 1 & 0.01 & 1 & 0.01 & 1 & 0.01 & 1 & 0.01 & 2 & 0.02 & 2 & 0.02 \\
\hline \multicolumn{18}{|c|}{\begin{tabular}{|l|} 
Peluang (Opportunity) \\
\end{tabular}} \\
\hline $\begin{array}{l}\text { 1. Pemda } \\
\text { memiliki } \\
\text { tekad untuk } \\
\text { berperan } \\
\text { dalam } \\
\text { perkembanga } \\
\text { n pajak ikan } \\
\end{array}$ & 0.15 & 4 & 0.6 & 2 & 0.3 & 1 & 0.15 & 4 & 0.6 & 4 & 0.6 & 2 & 0.3 & 2 & 0.3 & 4 & 0.6 \\
\hline $\begin{array}{l}\text { 2. Akses jalan } \\
\text { fisik baik dan } \\
\text { terus } \\
\text { diperbaiki }\end{array}$ & 0.1 & 3 & 0.3 & 3 & 0.3 & 2 & 0.2 & 2 & 0.2 & 1 & 0.1 & 2 & 0.2 & 2 & 0.2 & 2 & 0.2 \\
\hline $\begin{array}{l}\text { 3. } \begin{array}{l}\text { Dekat dengan } \\
\text { stasiun dan } \\
\text { bandara }\end{array} \\
\end{array}$ & 0.1 & 2 & 0.2 & 4 & 0.4 & 2 & 0.2 & 2 & 0.2 & 4 & 0.4 & 3 & 0.3 & 2 & 0.2 & 3 & 0.3 \\
\hline 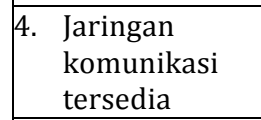 & 0.15 & 1 & 0.15 & 2 & 0.3 & 1 & 0.15 & 1 & 0.15 & 4 & 0.6 & 1 & 0.15 & 2 & 0.3 & 1 & 0.15 \\
\hline \multicolumn{18}{|c|}{ Ancaman (Threats) } \\
\hline $\begin{array}{l}\text { 1. Terbatsnya } \\
\text { lahan untuk } \\
\text { pembanguna } \\
\text { n }\end{array}$ & 0.15 & 1 & 0.15 & 4 & 0.6 & 1 & 0.15 & 4 & 0.6 & 1 & 0.15 & 4 & 0.6 & 1 & 0.15 & 2 & 0.3 \\
\hline \begin{tabular}{|l} 
2. $\begin{array}{l}\text { Listrik yang } \\
\text { kerap } \\
\text { bermasalah }\end{array}$ \\
\end{tabular} & 0.1 & 1 & 0.1 & 1 & 0.1 & 1 & 0.1 & 1 & 0.1 & 1 & 0.1 & 1 & 0.1 & 2 & 0.2 & 1 & 0.1 \\
\hline $\begin{array}{l}\text { 3. } \\
\text { kistem } \\
\text { yang belum } \\
\text { ada }\end{array}$ & 0.15 & 3 & 0.45 & 1 & 0.15 & 1 & 0.15 & 4 & 0.6 & 1 & 0.15 & 1 & 0.15 & 3 & 0.45 & 4 & 0.6 \\
\hline $\begin{array}{ll}\text { 4. } & \text { Tidak adanya } \\
\text { sistem } \\
\text { informasi } \\
\text { perjalanan }\end{array}$ & 0.05 & 4 & 0.2 & 1 & 0.05 & 1 & 0.05 & 4 & 0.2 & 1 & 0.05 & 1 & 0.05 & 1 & 0.05 & 4 & 0.2 \\
\hline \begin{tabular}{|l} 
5. Tidak adanya \\
kepastian \\
tarif
\end{tabular} & 0.05 & 1 & 0.05 & 1 & 0.05 & 1 & 0.05 & 1 & 0.05 & 1 & 0.05 & 1 & 0.05 & 1 & 0.05 & 1 & 0.05 \\
\hline TOTAL & & & 26 & & & & 6 & & 95 & & 59 & & 54 & & 19 & & 27 \\
\hline
\end{tabular}

AS = Nilai Daya Tarik (Attractiveness Score)

TAS = Total Nilai Daya Tarik (Total Attractiveness Score)

Nilai Daya Tarik : $1=$ Not acceptable

2 = Possibly acceptable

3 = Probably acceptable

$4=$ Most a cceptable 
Dari QSPM dapat dilihat bahwa nilai total kemenarikan relatif dari beberapa strategi alternatif secara berurutan adalah strategi SO1 dengan total skor 5.65, strategi W03 dengan skor 4.95, stratgei WO4 dengan nilai 4.58, strategi W01 dengan skor 4.34, strategi WT2 dengan skor 4.27, strategi ST1 dengan skor 3.54, strategi WT1 dengan skor 3.19 dan strategi WO2 dengan 2.6.

Berdasarkan hasil analisis QSPM tersebut maka strategi alternatif yang tertinggi yang menjadi pilihan untuk diterapkan dalam strategi pengembangan pasar tradisional pajak ikan kota Medan. Strategi yang tertinggi adalah strategi S01 (Strength - Opportunity) yaitu strategi yang menggunakan kekuatan internal dengan memanfaatkan peluang eksternal yang ada.

Strategi S01 juga dianggap sangat cocok bagi pengembangan pajak ikan, mengingat masih banyknya kekuatan yang ada pada outlet-outlet di pajak ikan ini. Adapun urutan prioritas 4 strategi tertinggi berdasarkan hasil penelitian strategi pengembangan pajak ikan kota Medan adalah sebagai berikut :

1. S01 (Mengadakan Event).

2. WO3 (Pembentukan organisass guna melatih dan memberdayakan SDM).

3. WO4 (Maksimalisasi TIS di Bandara untuk mendukung perkembangan wisata pajak ikan).

4. W01 (Penyediaan fasilitas untuk mendukung pelaksanaan kegiatan wisata).

\section{SIMPULAN DAN SARAN}

\subsection{Simpulan}

Pariwisata merupakan suatu aset bagi suatu daerah jika dikembangkan dengan baik, disamping daerah tersebut mendapatkan keuntungan finasial juga bagi masyarakat setempat sendiri dapat terkena dampak yang positif dari datangnya para pengunjung. Oleh sebab itu, suatu objek wisata yang berpotensi harus segera dikembangkan demi kemajuan suatu daerah. Tentunya hal terebut bergantung dari strategi apa yang diterapkan dalam pengembangannya. Salah satu alat untuk menemukan strategi apa yang cocok untuk pengembangan suatu tujuan wisata (destinasi), perencana wisata dapat menggunakan analisis matriks TOWS yang memberikan beberapa strategi alternatif yang dapat digunakan sesuai kriteria objek yang diteliti atau yang ingin dikembangkan.

Dalam matriks TOWS terdapat empat strategi alternatif yang baik untuk dijalankan untuk mengembangkan suatu daya tarik wisata khususnya pada outlet/usaha tanaman hias. Dari keempat strategi itu tidak semua strategi dapat dijalankan, untuk mencari strategi yang baik dari strategi-strategi alternatif yang telah dihasilkan dapat menggunakan QSPM (Quantitative Strategic Planning Matrix) yang mana dapat menghasilkan suatu strategi yang mempunyai daya tarik relatif dari strategistrategi yang dihasilkan pada matriks TOWS.

Penulis dapat menyimpulkan strategi yang tepat bagi pengembangan objek wisata berdasarkan analisis penilaian dengan menggunakan QSPM yaitu, pasar tradisional pajak ikan di kota Medan memiliki potensi wisata untuk sebuah daerah tujuan wisata yaitu dengan strategi beberapa strategi yang telah diurutkan penilaiannya sebagai berikut :

1. S01 (mnegadakan event atau kontes)

2. WO3 (pembentukan organisasi guna melatih dan memberdayakan SDM)

3. Wo4 (maksimalisasi TIS di Bandara untuk mendukung perkembangan wisata pajak ikan)

4. W01 (penyediaan fasilitas untuk mendukung pelaksanaan kegiatan wisata)

5. WT2 (pengembangan sistem keselamatan dan keamanan dalam lingkup sistem infromasi perjalanan)

6. ST1 (zonasi kawasan)

7. WT1 (penataan ruang dan toko yang lebih berorientasi pada fungsi)

8. WO2 (perbaikan fasilitas kebersihan hulu).

\subsection{Saran}

a. Pedagang masyarakat sekitar, pemerintah (birokrat) dan akademisi sebaiknya duduk bersama untuk menelaah potensi yang ada di pajak ikan. Sebagai pemangku kepentingan, pemerintah harus dapat berperan lebih untuk memfasilitasi kepentingan yang lebih luas. Program pelaksanaan berbagai event di pajak ikan bukanlah sebuah omong kosong jika diterapkan. Kondisi fisik di pajak ikan cukup mendukung untuk melaksanakan event ini, apalagi lokasi pajak ikan yang sangat menguntungkan. Akan lebih baik jika ada unsur pelibatan objek wisata sekitar untuk mendukung gagasan ini. 
b. Sebaiknya dibentuk organisasi pengelola yang mewadahi aspirasi pedagang dan menjadi lembag yang dapat menjembatani kepentingan pedagang kepada pemerintah dan pihak terkait lainnya. Organisasi pengelola ini dapat berupa koperasi bersama atau komunitas pedagang pajak ikan dan lain-lain.

c. Perlu dilaksanakan pelatihan dan pemberdayaan pengelola dan pramuniaga dalam keterampilan melayani pembeli. Pelatihan pelayanan prima dengan materi sejenis seni dalam menjual dan packaging adalah salah satu contoh gagasan pelatihan yang dapat diterapkan. Pelatihan kemampuan komunikasi dalam bahasa inggris untuk pramuniaga juga dianggap perlu. Bahkan dengan adanya lembaga sertifikasi profesi pihak ketiga, dimungkinkan pelatihan-pelatihan tersebut akan menghasilkan pengakuan kompetensi bagi peserta pelatihan berbentuk sertifikasi.

d. Keberadaan tourism information service di Bandara dapat dimanfaatkan untuk menginformasikan keberadaan pajak ikan. Pencantuman pajak ikan dengan informasinya yang lengkap di brosur wisata yang dibagikan kepada wisatawan di TIS merupakan contoh kongkret strategi ini. Hal ini juga didukung dengan lokasi bandara yang dekat dan mudah diakses dari pajak ikan.

e. Pengadaan fasilitas umum yang mendukung kegiatan wisata juga mutlak dilaksanakan. Fasilitas toilet umum sangat dibutuhkan dan terkesan mendesak untuk saat ini. Selain diadakan, harus diikutsertakan sistem perawatan dan perbaikan secara kontinu. Fasilitas mushola juga perlu didirikan, mengingat kebanyakan pedagang berasal dari komunitas mandailing, padang dan India/Arab yang notabene beragama Islam. Dengan keterbatasan fasilitas-fasilitas ini mudah diakses nantinya. Dengan keterbatasan lahan yang ada, maka akan sedikit sulit untuk merealisasikan hal ini. Namun dengan mengambil alih beberapa tokoh atau perencanaan ulang maka pembangunan fasilitas ini dapat terlaksana. f. Selain itu diperlukan juga penelitian lanjutan mengenai ide pengembangan Pajak Ikan sebagai pusat belanja wisata di kota Medan.

\section{DAFTAR PUSTAKA}

Angipora, Marius. 2002. Dasar-dasar Pemasaran. Jakarta : PT. Raja Grafindo Persada.

Oka A.Yoeti,1996. Pengantar Ilmu Pariwisata, Angkasa Bandung.

Agrowisata Sebagai Pariwisata Alternatif, I Gusti Bagus Rai Utama,

http://www.gdnet.org/fulltet/1164925881_Buku_ Agrowisata.doc.

Budianan N S. 2007. Memupuk Tanaman Hias. Jakarta : Penebar Swadaya.

Depta, 2005. “Agrowisata Meningkatkan Pendapatan Petani" pada http://database.deptan.go.id.

Garsinia Lestari \& Ira Puspa Kencana. 2008. Galeri Tanaman Hias Lanskap. Jakarta : Penebar Swadaya.

Juwita Ratnasari, 2007. Galeri Tanaman Hias Bunga, Jakarta : Penebar Swadaya.

Kusmayadi dan Endar Sugiarto. 2000. Metodologi Penelitian dalam Bidang Kepariwisataan. Jakarta:PT.Gramedia Pustaka Utama.

Naskah Yayasan Bina Pembangunan, 1990. Pariwisata Citra \& Manfaatnya. Jakarta : PT. Bina Rena Pariwsara (51-52).

Strategi Pengembangan Wisata Agro di Indonesia, 2005, 29 Oktober 2008. (http://database.deptan.go.id).

Syamsu dkk. 2001. "Penerapan Etika Perencanaan pada kawasan wisata, studi kasus di kawasan agrowisata Salak Pondoh, Kabupaten Sleman Daerah Istimewa Yogyakarta" Jakarta:LP3M STP Tri Sakti, Jurnal Ilmiah, Vol 5. No. 3 Maret 2001.

Sugiyono, 2007, Metode Penelitian Bisnis : Bandung : PT> Balai Pustaka.

Suyitno, 2001. Perencanaan wisata. Yogyakarta : Kanisius.

Spillane, James.1994. Pariwisata Indonesia : Siasat Ekonomi dan Rekayasa Kebudayaan. Yogyakarta:Kanisius.

UU NO. 9 Tahun 1990, 29 Oktober 2008. http://www.ditjenphka.go.id/peraturan_file/uu/1 1._NOMOR_9_TAHUN_1990.pdf. 